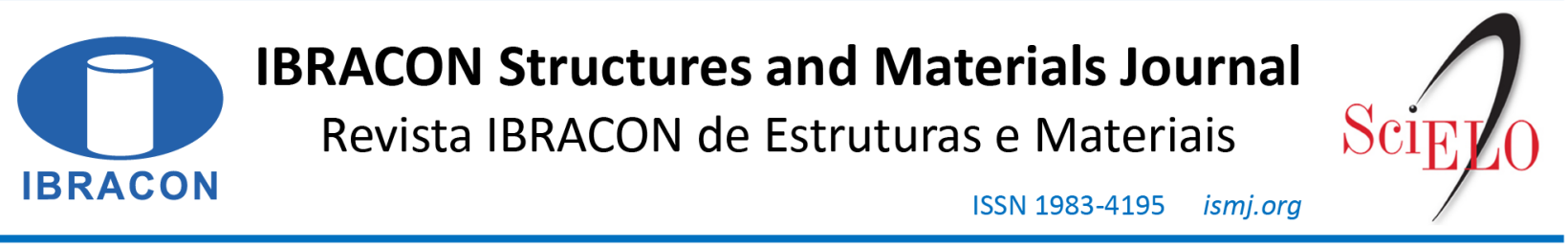

ORIGINAL ARTICLE

\title{
Experimental evaluation of induced human walking vibrations on steel-concrete composite floors
}

\section{Avaliação experimental do comportamento dinâmico de pisos mistos (aço- concreto) submetidos ao caminhar humano}

\author{
Bárbara Elisa Ferreira ${ }^{a}$ \\ Hermes Carvalho ${ }^{\mathrm{a}}$ \\ José Guilherme Santos da Silva ${ }^{\mathrm{b}}$ \\ Rodrigo Barreto Caldas ${ }^{\mathrm{a}}$ \\ Jefferson Viana Aguiar ${ }^{\mathrm{b}}$
}

${ }^{a}$ Universidade Federal de Minas Gerais - UFMG, Departamento de Engenharia de Estruturas, Belo Horizonte, MG, Brasil

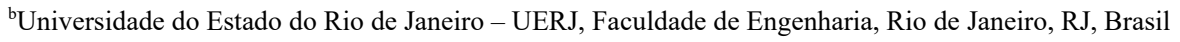

Received 23 September 2020

Accepted 06 November 2020

\begin{abstract}
This work presents the experimental evaluation of the dynamic behavior of Steel and concrete composite floors, from a human comfort point of view, when submitted to human walking. The structural model investigated was a real composite floor system under construction, with a total area of approximately $1300 \mathrm{~m}^{2}$. A preliminary numerical model was developed in order to guide the ideal positioning of excitation and instrumentation to be adopted in the experimental "in situ" evaluation. Next, free vibration tests were carried out to obtain the modal parameters of the structure. More than 180 forced vibration tests with excitation caused by a person walking at different step frequencies and directions were performed to determine de maximum structure's response. The results found were compared with human comfort criteria recommended by national and international standards and design guides. Subsequently, a people quantity influence analysis on the dynamic response of the floor was carried out, where it was noticed that the increase in the number of users walking on the floor also increased the peak acceleration value. This fact emphasizes the need to carry out experimental evaluations considering the variation of people quantity on floor activity in order to evaluate the real scenario of human vibrations induced in the structure under service.
\end{abstract}

Keywords: experimental dynamic analysis, human comfort assessment, steel-concrete composite floor, numerical modeling.

Resumo or Resumen: O presente trabalho apresenta a avaliação experimental do comportamento dinâmico de
pisos mistos (aço-concreto), sob o ponto de vista do conforto humano, quando submetidos ao caminhar humano.
O modelo estrutural investigado foi um sistema de piso misto (aço-concreto) real e em fase de construção, com
área total aproximada de $1300 \mathrm{~m}^{2}$. Um modelo numérico preliminar foi elaborado visando nortear o
posicionamento ideal da excitação e instrumentação a ser adotada no ensaio experimental in loco. A partir do
programa experimental definido, testes de vibração livre foram realizados para determinar os parâmetros modais
da estrutura. Cerca de 180 ensaios de vibração forçada sob a excitação causada pelo caminhar de uma pessoa em
diferentes frequências de passo e direções foram realizadas para determinar as respostas máximas do piso. Os
resultados encontrados foram comparados com critérios de conforto humano recomendados por normas e guias
de projeto nacionais e internacionais. Posteriormente, realizou-se uma análise da influência do número de pessoas
na resposta dinâmica do piso, sendo observado que o aumento da quantidade de usuários caminhando sobre o
piso acarretou no acréscimo do valor da aceleração de pico. Tal fato enfatiza a necessidade da realização de
avaliações experimentais considerando a variação da quantidade de pessoas exercendo atividades sobre o piso,
de forma a representar as vibrações induzidas nas situações reais de serviço da estrutura. Palavras-chave: análise dinâmica experimental, conforto humano, pisos mistos (aço-concreto), modelagem numérica.

How to cite: B. E. Ferreira, H. Carvalho, J. G. S. Silva, R. B. Caldas, and J. V. Aguiar, "Experimental evaluation of induced human walking vibrations on steel-concrete composite floors," Rev. IBRACON Estrut. Mater., vol. 14, no. 4, e14406, 2021, https://doi.org/10.1590/S1983-41952021000400006

Corresponding author: Barbara Elisa Ferreira. E-mail: barbara.elisaf@gmail.com

Financial support: None.

Conflict of interest: Nothing to declare. 


\section{INTRODUCTION}

Steel and concrete composite structures have been consolidated as a strong technological alternative in the Brazilian civil construction scenario, being increasingly adopted in commercial, parking, and residential buildings. On the other hand, with the emergence of materials with greater resistance, it has become increasingly feasible to reduce the total height of a composite floor system, seeking useful space improvement. However, this trend implies in reducing the system's stiffness, making these structures increasingly susceptible to the effects of dynamic loads induced by human activities, causing discomfort to users or even structural problems. For this reason, several authors [1]-[10] have developed important research with consistent and qualified investigations regarding the consideration of dynamic actions in the design of structures for human comfort assessment, based on experimental data and finite element models. Dynamic tests are a convenient way for the evaluation of existing or under construction structures due to their nondestructive character, and, therefore, allows to obtain real modal parameters in multiple regions. Based on real values for such parameters, the structure evaluation in relation to acceptable vibration levels is performed with greater reliability.

Varela and Battista [6] related problems with excessive vibration in steel and concrete composite floor and discomfort to users even when the structures met the criteria established in structural design standards. Dallard et al. [11] argues in his work that excessive structural vibration disturbs users in their activities and that the structures may even be rendered unusable or considered unsafe due to panic caused among people due to vibrations. Varela [12] found experimentally that problems due to dynamic excitations produced by human activities are more acute and frequent in continuous slab panels, as they have multi-vibration modes.

Most studies and standards report that human discomfort occurs in structures with a natural frequency below $8 \mathrm{~Hz}$, however, Brownjohn and Middleton [13] analysed in their study that structures with a frequency above $10 \mathrm{~Hz}$ also presented significant dynamic responses. Araújo and Costa [14] also came to similar findings. The authors studied the dynamic behavior of three concrete slabs and realized that, despite the displacements found in these structures meeting the recommendations of ABNT NBR 6118 [15], the peak accelerations for models with a natural frequency greater than $10 \mathrm{~Hz}$ exceeded the imposed limits for human comfort. Gaspar [16] experimentally evaluated the structural system flexibility influence during the practice of rhythmic activities, concerning human comfort, performing tests on rigid and flexible floors. The author noted, as expected, the accelerations in time tended to decrease as the frequencies of activity and their respective harmonics moved away from the floor fundamental frequency. However, the values found for these cases were higher than the human comfort limits imposed in the literature, indicating that the comfort assessment for frequencies further from resonance should not be neglected. These facts demonstrate that the influence and contribution of the highest harmonics of human walking should not be underestimated with regard to human comfort.

People and structure movement synchronization is a case of human-structure interaction and this behavior has been studied at different times as reported by Nakamura et al. [17] and Matsumoto and Griffin [18]. Shahabpoor et al. [19] analysed the human presence influence in altering the structure modal parameters, concluding that the actions exercised by people tend to considerably increase structural damping, but cause small changes in natural frequencies. The authors also found that the change in the structure modal parameters becomes more significant as the number of people involved in the activities increases. Venuti et al. [21] demonstrated that, in addition to the dynamic structure-pedestrian interaction, it is also important to analyse the different walking paths that can be performed by users, as well as speed and step length. Following this same line of study, Zhang and $\mathrm{Xu}$ [22] carried out a parametric analysis in order to determine the difference in floor responses associated with four walking paths: parallel and perpendicular to the floor beams, diagonal and circular. The authors concluded that the path leads to the greatest responses depends on the floor attachment conditions.

Therefore, in view of the growing number of human comfort problems reported in composite structures, this study aims to study a real composite floor (steel-concrete) dynamic response, located in Belo Horizonte city, when subjected to human walk loads. The structure modal properties are determined by experimental and numerical analysis, with subsequent comparison between them. In the floor experimental analysis, different dynamic actions are evaluated, thus allowing the structure peak accelerations determination, as well as the dependence of these responses on the excitations imposed on the structure. Finally, this work also presents the objective of evaluating the human comfort levels of the floor regarding the vibration acceptable limits. 


\section{STRUCTURE DESCRIPTION}

The investigated structure corresponds to an existing building, which is under construction and was designed to be a teaching hospital for a private University in the city of Belo Horizonte / MG, Brazil (Ferreira [23]). Its structural system is based on composite floors (steel-concrete), composed of concrete slabs supported by steel beams, with twelve floors. Each building floor has a total area of approximately $1300 \mathrm{~m}^{2}$. Figure 1 shows a standard floor (8th floor), with typical height between occupable floors of 3.40 meters. Three floors between axes A and C and two floors located between axes 1' and 3' were studied.

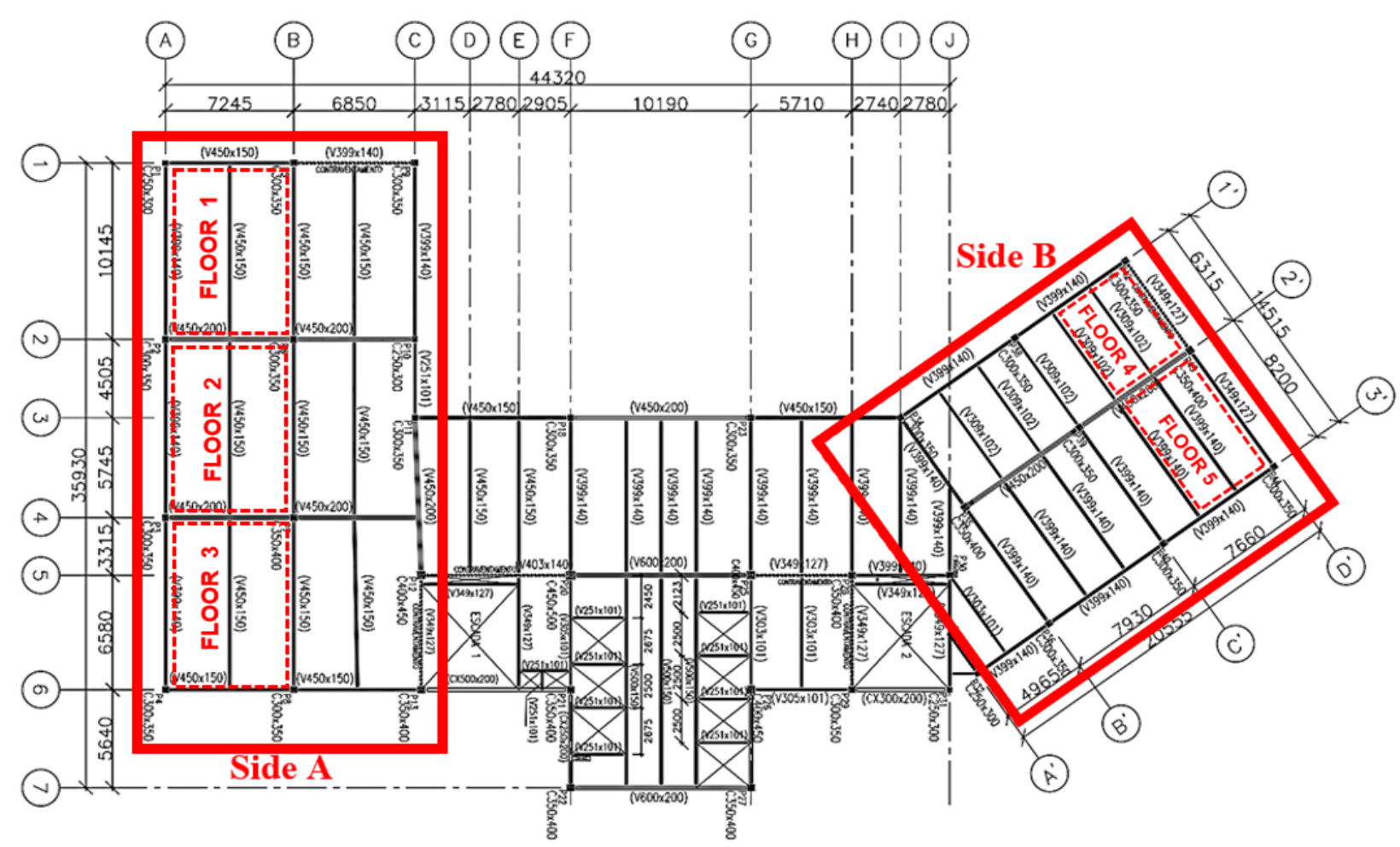

Figure 1. Composite floor (steel-concrete) investigated: $8^{\text {th }}$ floor [mm].

The building columns and beams are made of welded steel profiles, with geometric dimensions and properties according to the project and the columns are made up of welded box-shaped profiles, filled with concrete (Figure 2 and Figure 3). The composite slabs are of steel deck type with total thickness of $150 \mathrm{~mm}$, mold by Metform type MF75 and thickness of $0.85 \mathrm{~mm}$ or $0.95 \mathrm{~mm}$. In addition, the floor has a 1.5 -meter-high masonry throughout the perimeter, stairway boxes and elevator boxes, aspects that should be considered in the numerical modelling of the structure. The

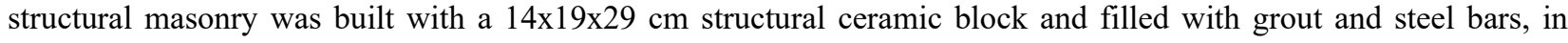
addition to concrete strapping.

In relation to the materials physical characteristics, the concrete has a characteristic compressive strength $\left(f_{c k}\right)$ equal to $30 \mathrm{MPa}$, Young's modulus $\left(E_{c}\right)$ of $38 \mathrm{GPa}$, Poisson's ratio $\left(v_{c}\right)$ equal to 0.2 and specific weight $\left(\gamma_{c}\right)$ of $2500 \mathrm{kgf} / \mathrm{m}^{3}$; and the steel has a yield strength $\left(f_{y}\right)$ of $345 \mathrm{MPa}$, Young's modulus $\left(E_{s}\right)$ of $200 \mathrm{GPa}$, Poisson's ratio $\left(v_{s}\right)$ equal to 0.3 and a specific weight $\left(\gamma_{s}\right)$ of $7849.05 \mathrm{kgf} / \mathrm{m}^{3}$. The material properties were obtained in the building's original structural drawings, made available by Codeme Engenharia S/A, the company responsible for the structure execution. For the structural masonry, a module of longitudinal elasticity $\left(E_{a}\right)$ of $20.4 \mathrm{GPa}$ was adopted, Poisson's ratio $\left(v_{a}\right)$ equal to 0.15 and specific weight $\left(\gamma_{a}\right)$ of $1250 \mathrm{kgf} / \mathrm{m}^{3}$, according to the criteria established by ABNT NBR 15812-1 standard [24], due to absence of tests or accurate information about the characteristics of the block. 


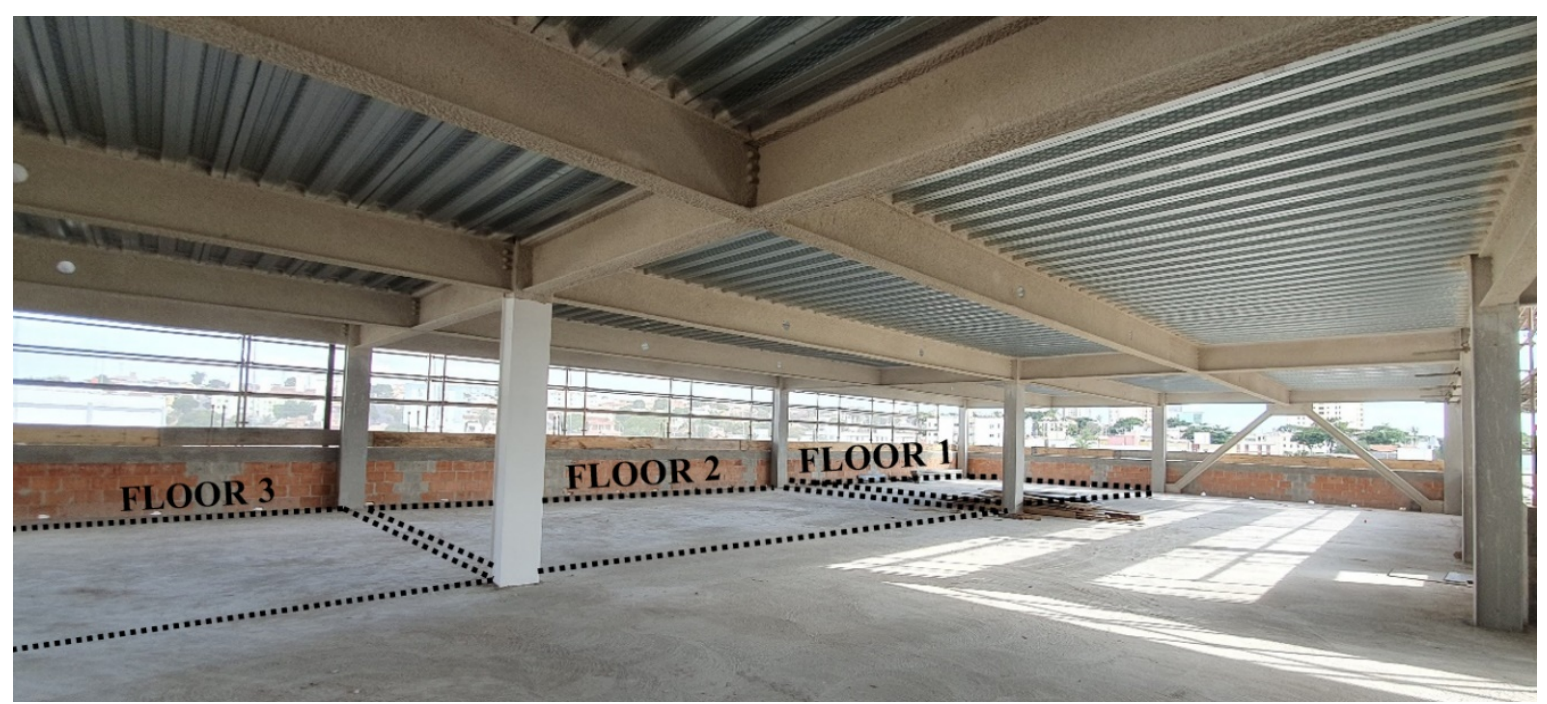

Figure 2. Identification of floors 1, 2 and 3 (Side A).

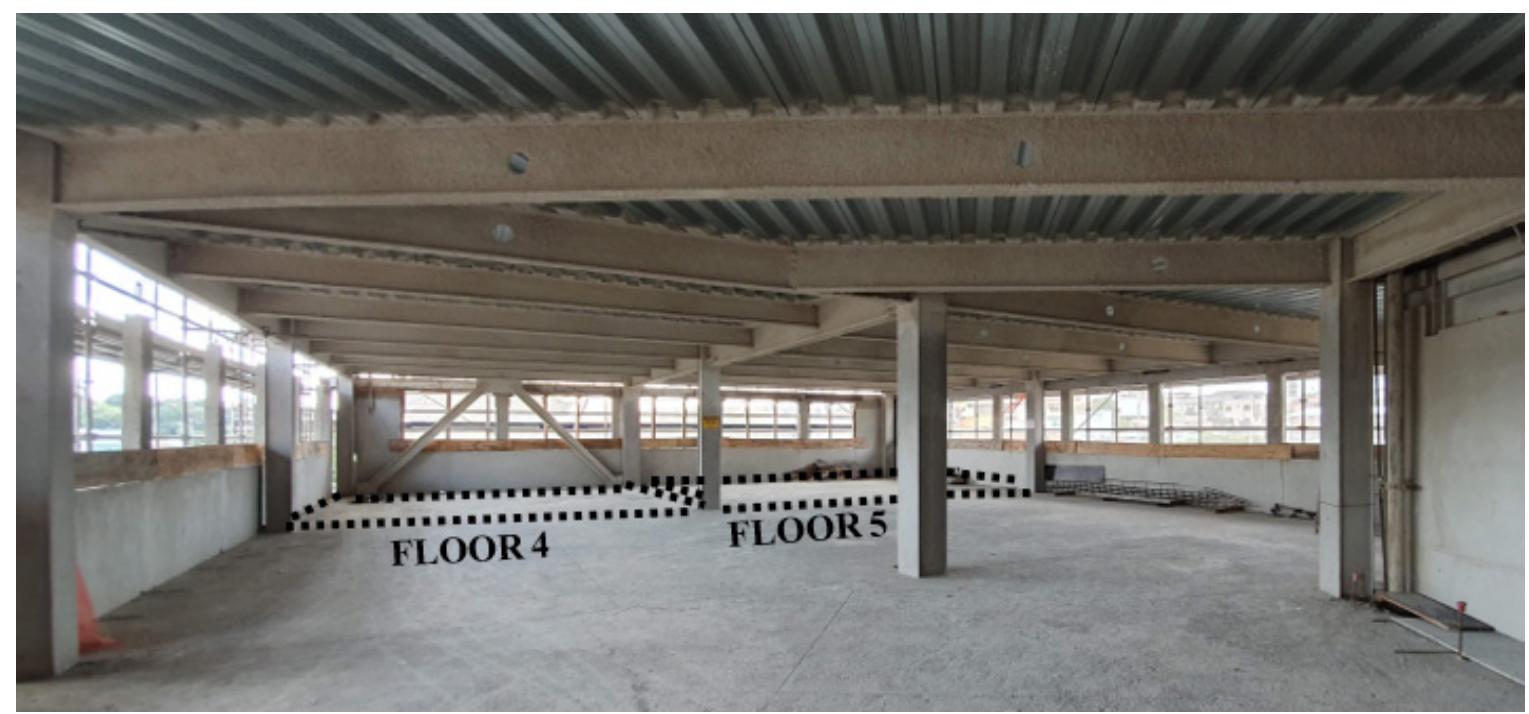

Figure 3. Identification of floors 4 e 5 (Side B).

\section{NUMERICAL MODEL}

The numerical model developed for composite floors (steel-concrete) modal analysis adopted the usual discretization techniques associated with the Finite Element Method (FEM), based on the computer program ANSYS [25]. In this computational model, all beams and columns were represented by the element BEAM44, where the effects of bending and torsion are considered. The BEAM44 corresponds to a uniaxial element composed of two nodes and each one with six degrees of freedom: translations and rotations in $\mathrm{X}, \mathrm{Y}$ and $\mathrm{Z}$. This element allows considering the nodes to be separated from the centroid axis. This eccentricity should be considered in the beams modelling, since the slab and beam are not positioned on the same axis and affects directly the structure's natural frequencies. Reinforced concrete slabs and masonry were simulated using shell elements type SHELL63, based on thin plate theory and defined by four nodes with six degrees of freedom in each node, three of translation and three of rotation in directions $\mathrm{X}, \mathrm{Y}$ and $\mathrm{Z}$.

The numerical model showed 8089 nodes, 9338 elements, and 48294 degrees of freedom, as can be seen in Figure 4. The complete interaction between the concrete slabs and the steel beams was considered in the study through knot coupling of the three-dimensional shell and beam elements, simulating the behaviour of a composite structural system. Linear, elastic and isotropic behaviour was considered for steel and concrete materials, and all sections of 
the structural model remained flat in the deformed state. The boundary conditions considered restricted the columns' base and top nodes over half high above and below the analysed system floor, so that they are prevented from moving translationally, in the horizontal and vertical plane. The secondary beams connection nodes with the main beams were modelled as rigid nodes.

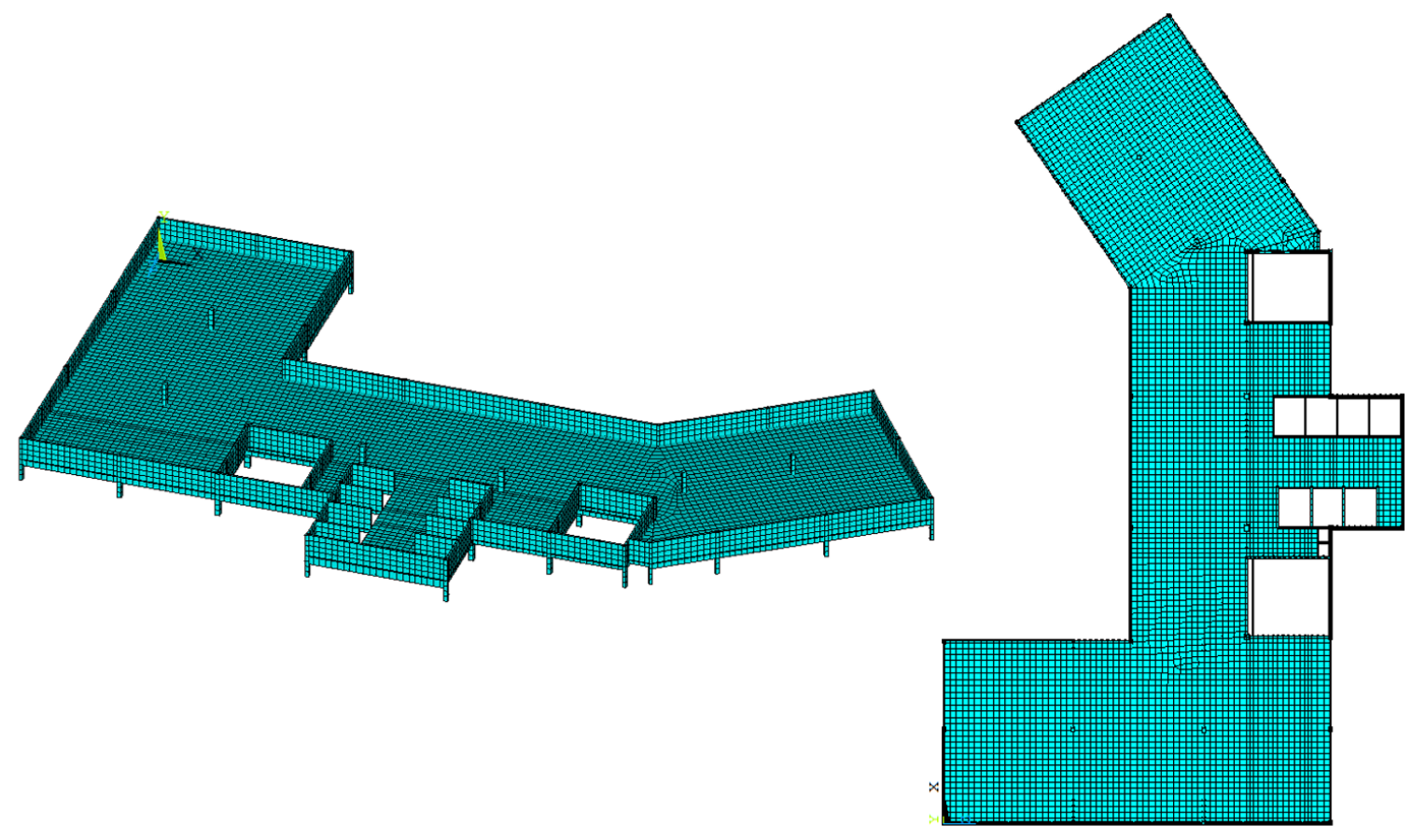

Figure 4. Investigated composite floor (steel-concrete) finite element model.

\section{EXPERIMENTAL ANALYSIS}

The on-site experimental program was divided into two stages. Firstly, free vibration tests were carried out to obtain the modal parameters of the structure - natural frequencies, modal shapes and modal damping rate. Secondly, forced vibration tests were performed, represented by the walking of a person in a controlled manner, to obtain the dynamic responses of the floors. The tests were carried out on previously defined floors and their results provided real parameters for the FEM model evaluation in terms of its dynamic and users' comfort characteristics, using national and international standards criteria and practical guides.

The floors experimental modal analysis was carried out by means of "in situ" dynamic monitoring, through the installation of PCB Piezotronics seismic accelerometers, model 393B04, connected to a data acquisition system from Bruel and Kjaer, model 3050-A-060. The free vibration test was carried out in such a way that the floors were excited by the impact of a $106.2 \mathrm{~kg}$ person, using boots with flexible plastic soles, jumping in their respective centres at a height of $0.48 \mathrm{~m}$. Each floor was excited by three impacts, with sufficient time intervals between each one to dampen vibrations in the dominant modes. Each test procedure was repeated three times on each floor, totalling fifteen tests on the entire floor, and only the most relevant results are presented in this paper. Modal analysis tests were performed to obtain natural frequencies, time functions associated with accelerations in relevant structural sections of the structure and damping coefficients. The method used in this work was Single Input Multiple Output data (SIMO), a technique commonly used in experimental dynamic monitoring of structures (Brandt [26], Cunha and Caetano [27]).

Before the experimental modal tests, the main structure's vibration modes behaviour was investigated through the numerical model, aiming to find common floor points that would excite the largest number of modes. Then, five points were chosen in this analysis, in order to obtain the investigated system floor modal parameters. These points of interest are illustrated in Figure 5. 


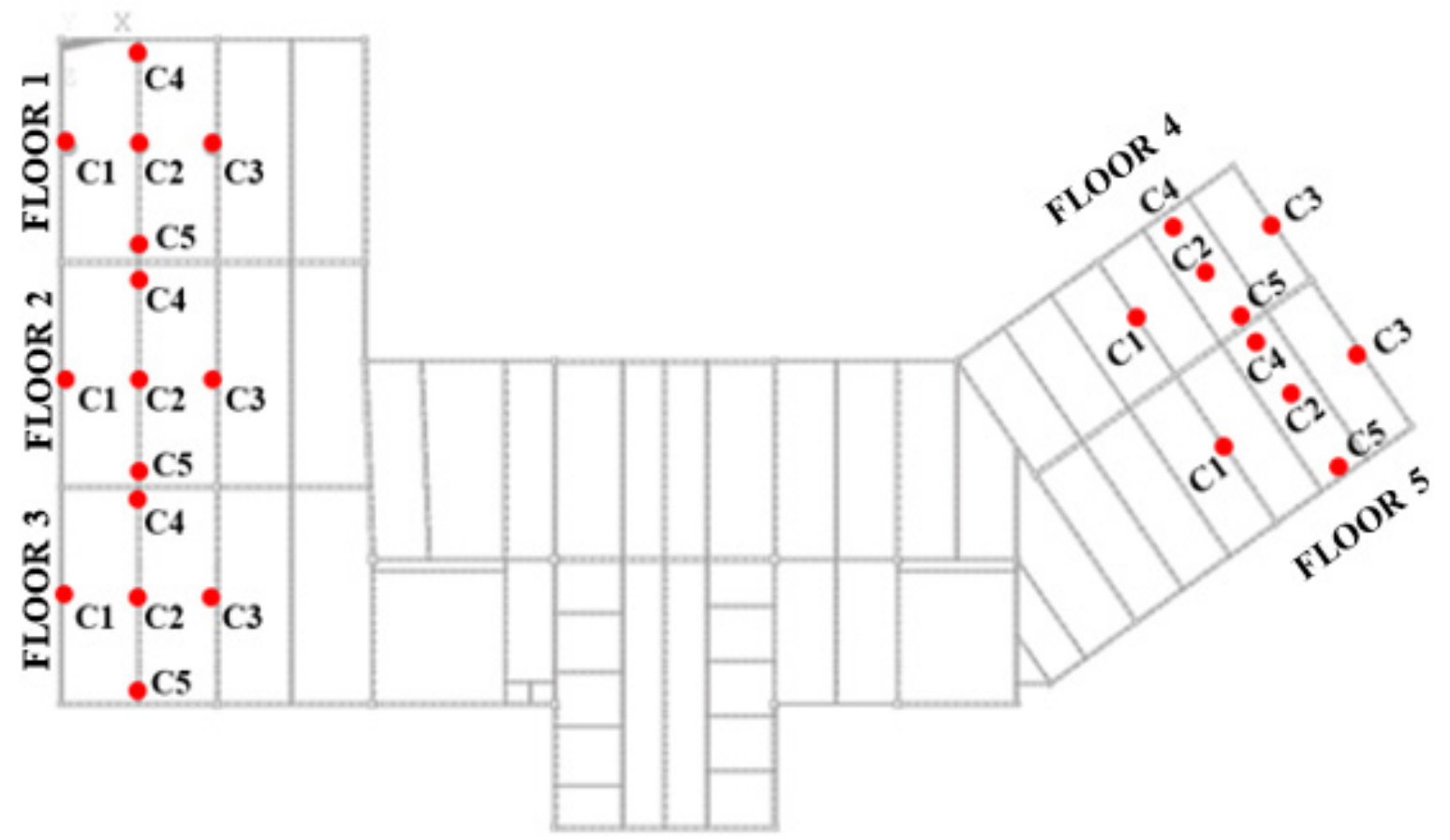

Figure 5. Instrumentation points over the five tested floors.

The dynamic responses of the floor were obtained when a person walked on the structure, with step frequencies controlled in previously defined or random directions. Figure 6 illustrates typical walking paths. Each of these trajectories was executed three times on each floor, with a complete execution characterized by three back and forth walks. Table 1 summarizes the performed tests, with 36 tests per floor and 180 tests on the system floor. A metronome was used to control step frequency and maintain the pace of human walking on the structure. The representative unit for metronome is "bpm" (beats per minute). Thus, each sound beat corresponds to the contact of each step in the structure. The metronome was set at $102 \mathrm{bpm}(\mathrm{fp}=1.7 \mathrm{~Hz})$ to induce a slow walk, $120 \mathrm{bpm}(\mathrm{fp}=2.0 \mathrm{~Hz})$ to induce a normal walk and $138 \mathrm{bpm}(\mathrm{fp}=2.3 \mathrm{~Hz})$ to lead to a fast walk.

In order to assess the number of people walking on the floor dynamic response influence, the monitoring of floor 1 was also carried out considering the walking of four people, with different biotypes and weights, in a slow ( $\mathrm{fp}=1.7$ $\mathrm{Hz})$, normal $(\mathrm{fp}=2.0 \mathrm{~Hz})$ and fast $(\mathrm{fp}=2.3 \mathrm{~Hz})$ step frequency. All types of walking took place in a random trajectory, as it better represents the situation of daily use. For this test, only one accelerometer was used, fixed in the centre of the slab (accelerometer C2), which represents the point of floor 1 fundamental modes greatest vibration amplitude, especially the first three modes. The results obtained from the tests were compared with those obtained for floor 1 excited by only one person and used in the floor in-service assessment with regard to human comfort, through the application of AISC DG 11 [1] and ISO 2631-2 [28].

Table 1. Total tests performed per floor.

\begin{tabular}{ccccc}
\hline Direction & Slow & Normal & Fast & Total by direction \\
\cline { 2 - 4 } & $\mathbf{1 . 7} \mathbf{~ H z}$ & $\mathbf{2 . 0 ~ H z}$ & $\mathbf{2 . 3} \mathbf{~ H z}$ & 3 \\
\hline Perpendicular & 3 & 3 & 3 & 9 \\
\hline Parallel & 3 & 3 & 3 & 9 \\
\hline Diagonal & 3 & 3 & 3 & 9 \\
\hline Random & 3 & 12 & 12 & $\mathbf{3 6}$ \\
\hline Total by frequency & 12 & & 3 \\
\hline
\end{tabular}




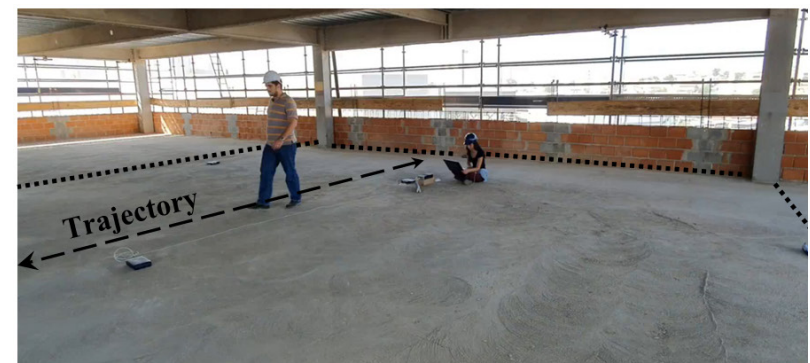

a) Perpendicular trajectory

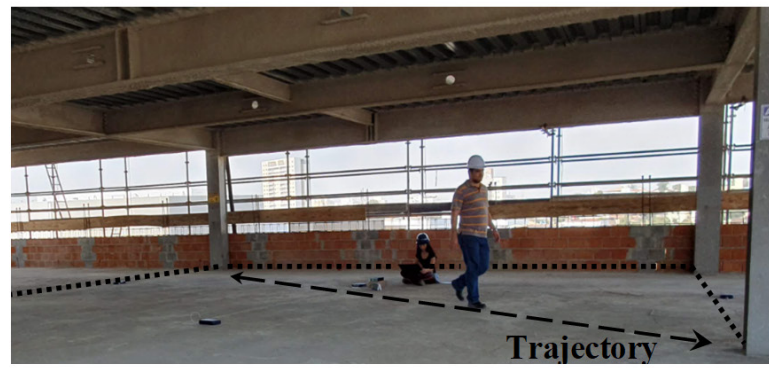

c) Diagonal trajectory

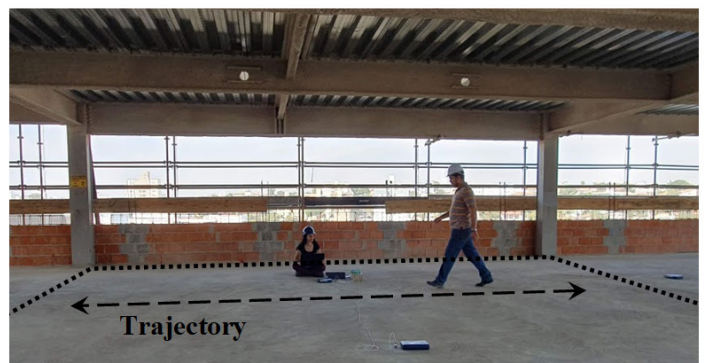

b) Parallel trajectory

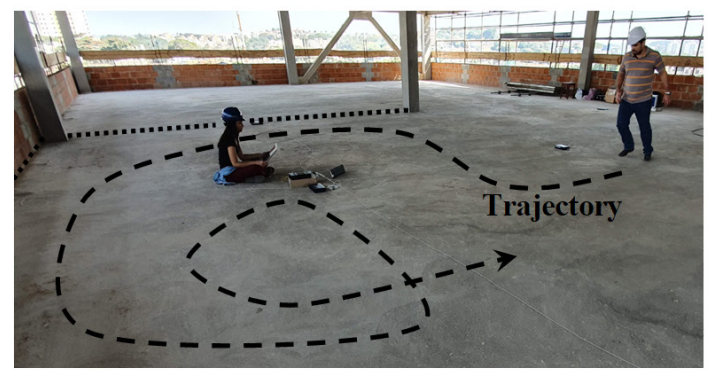

d) Random trajectory

Figure 6. Walking paths illustration.

\section{RESULTS AND DISCUSSIONS}

The results obtained in the "in situ" free and forced experimental vibration tests were processed and treated with MatLab platform, where signal filters recommended by ISO 2631-1 [29] and ISO 2631-2 [28] were applied.

\subsection{Free vibration}

The structure modal parameters - natural frequencies, vibration modes and modal damping rate - were determined by processing the vertical acceleration signals at the five points monitored in the free vibration experimental tests. Three free vibration tests were performed per floor, with three impacts in each test, totalling nine excitations per floor. The nine responses were grouped, and the graph obtained in the time domain for floor 1 is illustrated in Figure 7. It is observed that the series of impacts were carried out in sufficient time intervals to cushion the dominant modes amplitudes. The greatest acceleration amplitude occurred in the floor centres, close to the impact point as expected.

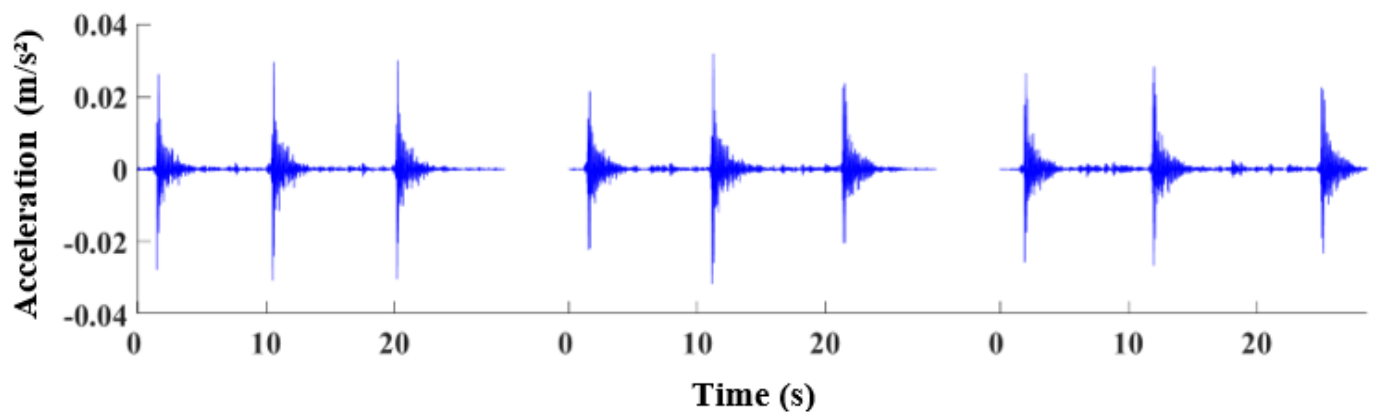

Figure 7. Acceleration x time recorded by channel 2, located at floor 1 centre.

Figure 8 presents the experimental results obtained in the frequency domain from the performed readings, in order to identify the eigenvalues that most collaborated with the chosen floor vibrations, with regard to the energy transfer for the system dynamic response. Analysing the results, it appears that the first three natural frequencies corresponding to the structure's first, second and third vertical vibration modes are $5.9 \mathrm{~Hz}, 6.5 \mathrm{~Hz}$ and $6.9 \mathrm{~Hz}$, respectively. 


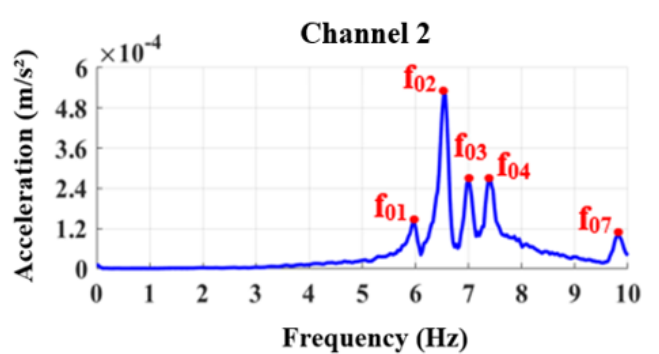

a) Floor $1\left(\mathrm{f}_{01}=5.9 \mathrm{~Hz} ; \mathrm{f}_{02}=6.5 \mathrm{~Hz} ; \mathrm{f}_{03}=6.9 \mathrm{~Hz}\right.$; $\left.\mathrm{f}_{04}=7.3 \mathrm{~Hz} ; \mathrm{f}_{07}=9.7 \mathrm{~Hz}\right)$

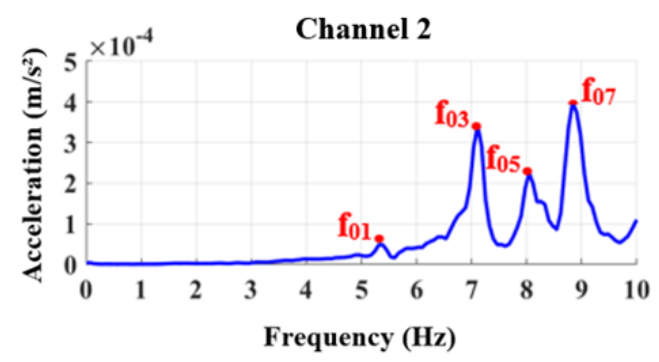

c) Floor $3\left(\mathrm{f}_{01}=5.3 \mathrm{~Hz} ; \mathrm{f}_{03}=7.1 \mathrm{~Hz} ; \mathrm{f}_{05}=8.0 \mathrm{~Hz}\right.$; $\left.\mathrm{f}_{07}=8.8 \mathrm{~Hz}\right)$

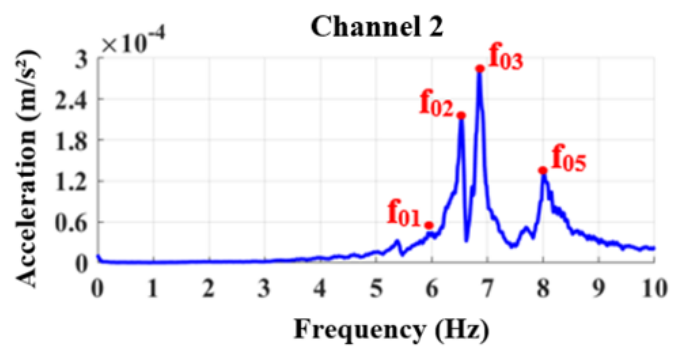

b) Floor $2\left(\mathrm{f}_{01}=5.9 \mathrm{~Hz} ; \mathrm{f}_{02}=6.5 \mathrm{~Hz} ; \mathrm{f}_{03}=6.9 \mathrm{~Hz}\right.$; $\left.\mathrm{f}_{05}=8.0 \mathrm{~Hz}\right)$

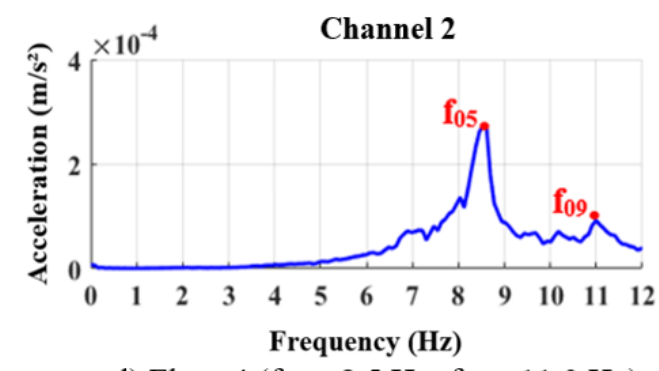

d) Floor $4\left(\mathrm{f}_{06}=8.5 \mathrm{~Hz} ; \mathrm{f}_{09}=11.0 \mathrm{~Hz}\right)$

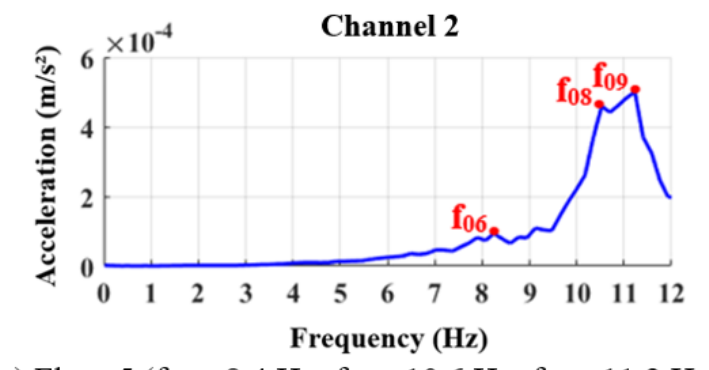

c) Floor $5\left(\mathrm{f}_{06}=8.4 \mathrm{~Hz} ; \mathrm{f}_{08}=10.6 \mathrm{~Hz} ; \mathrm{f}_{09}=11.2 \mathrm{~Hz}\right)$

Figure 8. Floor's vibration modes experimental FFT magnitudes.

It is worth mentioning that the system floor's first three natural frequencies are within the range of $5 \mathrm{~Hz}$ to $8 \mathrm{~Hz}$, which according to experimental studies related to human sensitivity is the interval people react in a particularly adverse way to vibrations. In addition, the fundamental frequency range of human walking presents values between $1.7 \mathrm{~Hz}$ and $2.3 \mathrm{~Hz}$, so the third or fourth harmonics of walking could coincide, or be quite close, to the first three floor's natural frequencies, leading to amplification of vibration amplitudes. Thus, the importance of carrying out forced vibration tests to assess the accelerations resulting from floor conditions for future users' human comfort analysis is evident.

The accelerations in the time domain were filtered in the first three vibration modes to determine modal damping (shown in Table 2) using the logarithmic decrement method. Figure 9 shows an example of the time-acceleration graphs filtered in the interest mode.

Most of the standards, design guides and relevant literature work estimate that the damping rate for finished offices' composite floors (steel-concrete) is in the range of $2 \%$ to $5 \%$ [1],[2],[4]. The damping rates of the floor under study were found outside this range, which was already expected and justified by the construction phase in which the building was at the time of the experimental tests, with the absence of non-structural elements that contribute to the increase in floor cushioning, such as: windows, partitions, furniture, coverings, among others.

Figure 10 illustrates, respectively, the first nine floor vibration modes obtained through the finite element model. It is observed that floors 1, 2 and 3, as they are structures with continuous slabs, present some similar vibration modes and natural frequencies with very close values, which makes it difficult to identify them in the experimental results. 
Table 2. Evaluated floor's natural frequencies comparison.

\begin{tabular}{ccccc}
\hline \multirow{2}{*}{ Mode Shape } & \multicolumn{2}{c}{ Natural Frequency $(\mathbf{H z})$} & Difference (\%) & $\begin{array}{c}\text { Damping Coefficient } \\
\text { (\%) }\end{array}$ \\
\cline { 2 - 3 } & Finite Element Model & Experimental Tests & & 1.2 \\
\hline $1^{\circ}$ & 5.71 & 5.90 & 0.2 & $1.03( \pm 0.19)$ \\
\hline $2^{\circ}$ & 6.49 & 6.50 & 1.4 & $1.19( \pm 0.21)$ \\
\hline $3^{\circ}$ & 6.87 & $6.97( \pm 0.12)$ & 0.7 & - \\
\hline $4^{\circ}$ & 7.61 & $7.67( \pm 0.35)$ & 3.3 & - \\
\hline $5^{\circ}$ & 8.17 & $8.45( \pm 0.21)$ & 3.7 & - \\
\hline $6^{\circ}$ & 8.71 & $8.40( \pm 0.57)$ & 5.2 & - \\
\hline $7^{\circ}$ & 9.24 & $9.75( \pm 0.07)$ & 3.1 & - \\
\hline $8^{\circ}$ & 10.08 & $10.40( \pm 0.28)$ & 3.7 & - \\
\hline $9^{\circ}$ & 10.69 & $11.10( \pm 0.14)$ & & - \\
\hline
\end{tabular}

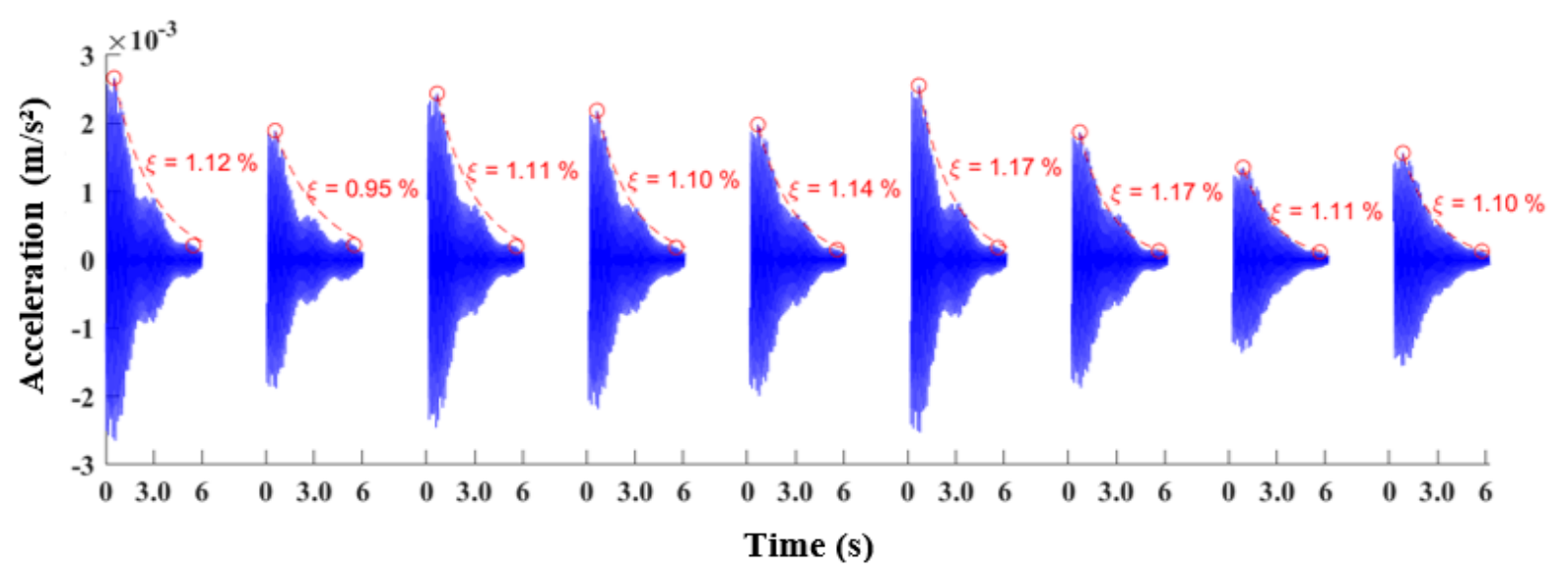

Figure 9. Example of the acceleration graph in the time domain filtered at the third mode.

Table 2 shows the comparison between the real structure tested natural frequencies and the respective numerical model. It is noted that the experimental results obtained for the five floors show a satisfactory agreement with each other, as well as when compared to the numerical results, with differences between $0.2 \%$ and $5.2 \%$, which indicates that the structural model under study is well calibrated and able to represent the structure behaviour. It is also worth mentioning that the agreement between the investigated floors dynamic structural responses obtained experimentally indicates a positive validation of the experimental tests developed.

\subsection{Forced vibration}

The experimental results associated with the greater dynamic structural response of each floor (vertical accelerations) are shown in Figures 11 to 16. These results were obtained in the time and frequency domains, respectively, corresponding to the output response associated with the accelerometers fixed in the floors centres (see Figure 5). 


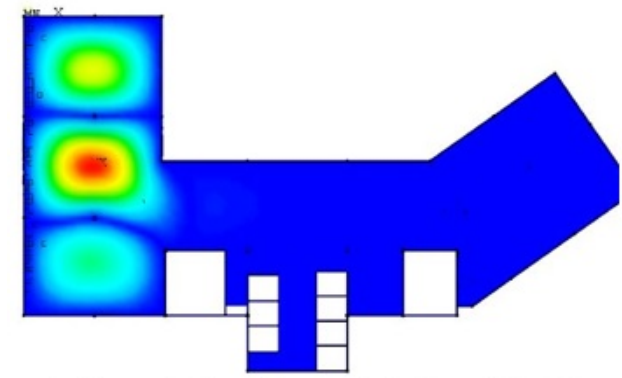

a) $1^{\text {st }}$ mode (bending mode): $f_{01}=5.71 \mathrm{~Hz}$

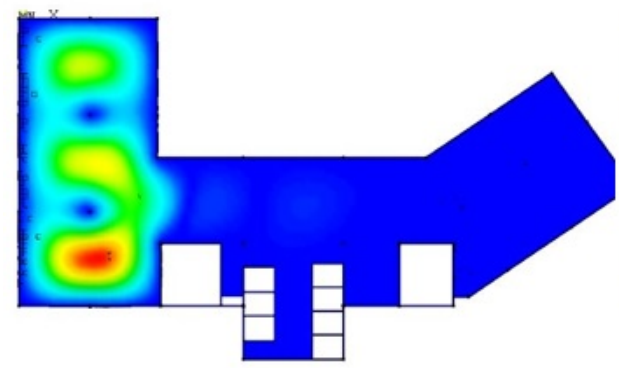

c) $3^{\text {rd }}$ mode (bending mode): $f_{03}=6.87 \mathrm{~Hz}$

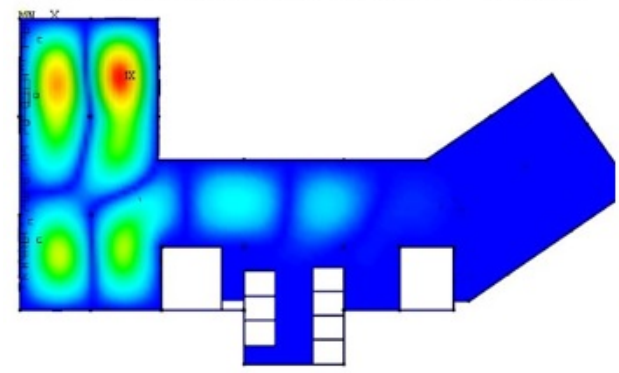

e) $5^{\text {th }}$ mode (bending mode): $f_{05}=8.07 \mathrm{~Hz}$

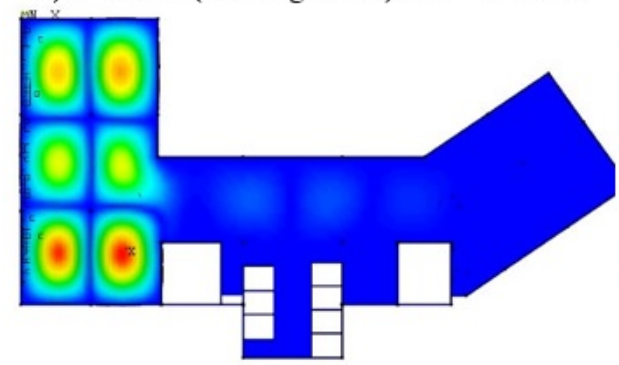

g) $7^{\text {th }}$ mode (bending mode): $f_{07}=9.24 \mathrm{~Hz}$

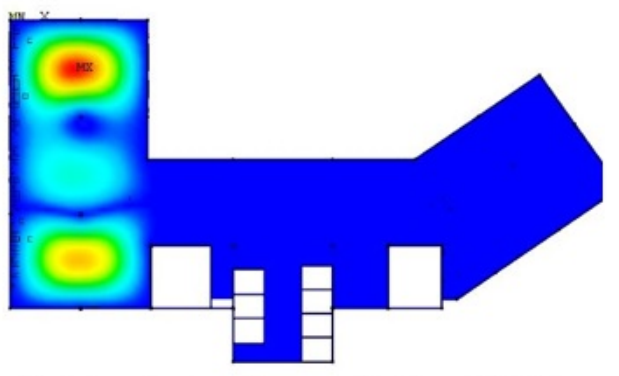

b) $2^{\text {nd }}$ mode (bending mode): $\mathrm{f}_{02}=6.49 \mathrm{~Hz}$

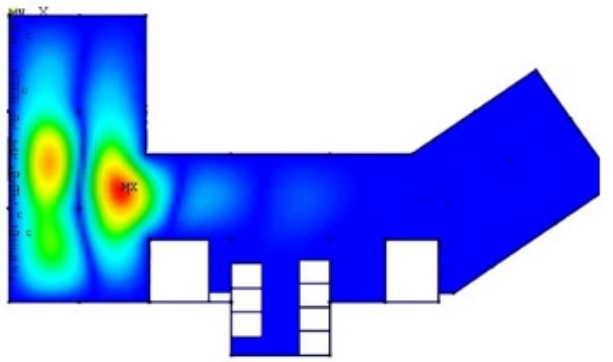

d) $4^{\text {th }}$ mode (bending mode): $\mathrm{f}_{04}=7.61 \mathrm{~Hz}$

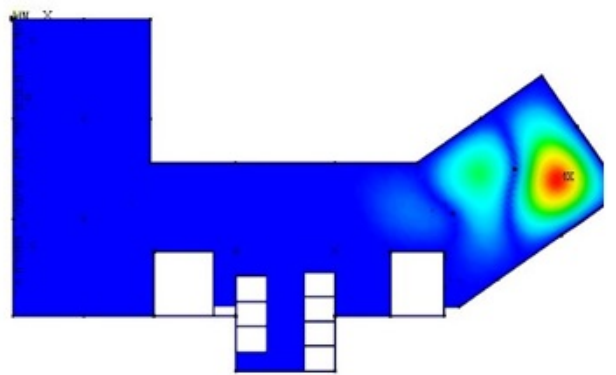

f) $6^{\text {th }}$ mode (bending mode): $\mathrm{f}_{06}=8.17 \mathrm{~Hz}$

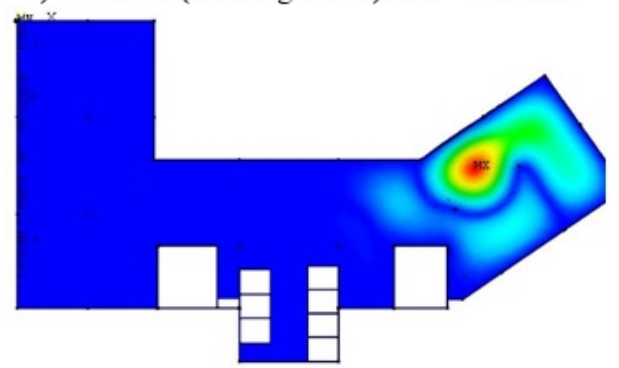

h) $8^{\text {th }}$ mode (bending mode): fos $=10.08 \mathrm{~Hz}$

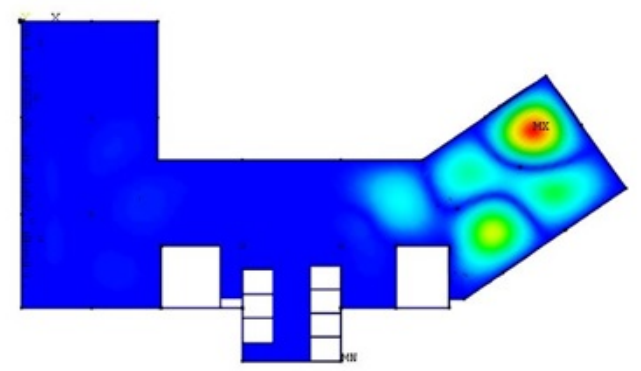

i) $9^{\text {th }}$ mode (bending mode): $\mathrm{f}_{09}=10.69 \mathrm{~Hz}$

Figure 10. Vertical bending vibration modes of the floors under study. 


\section{Channel 2}

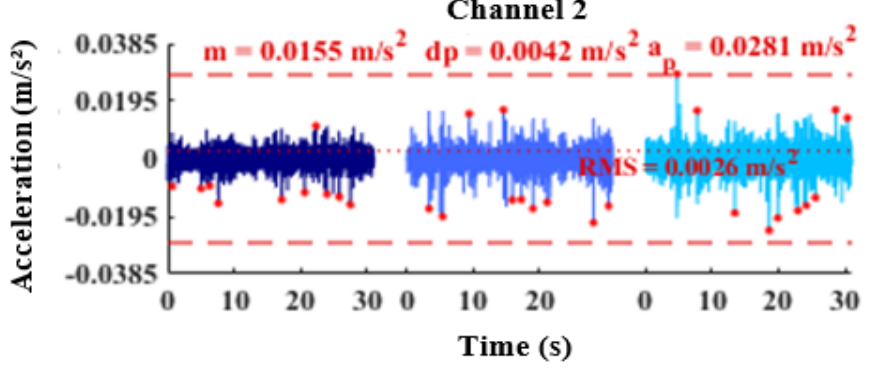

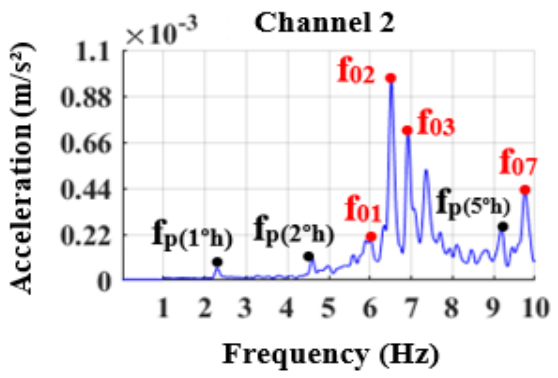

Figure 11. Dynamic response from floor 1 for fast walking on a random trajectory.
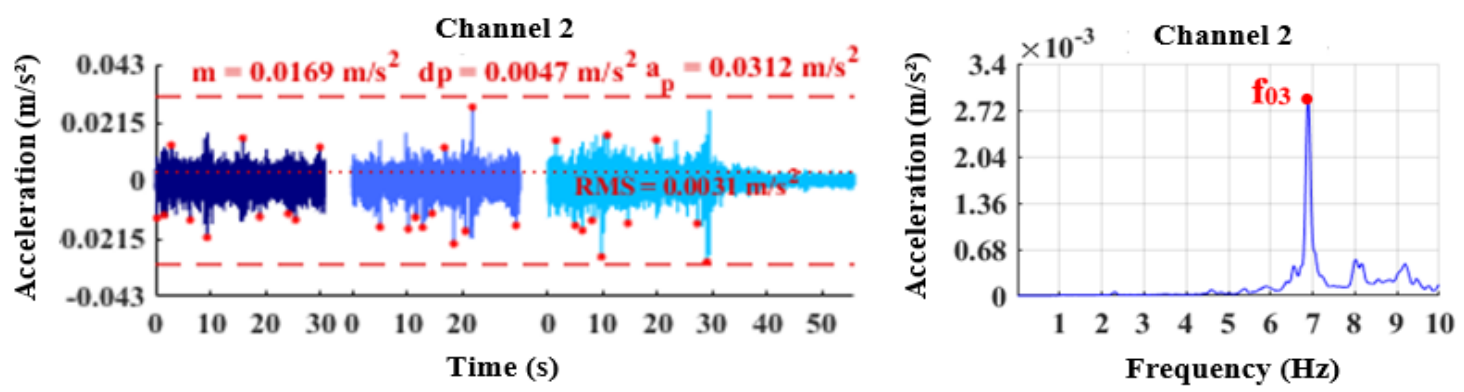

Figure 12. Dynamic response from floor 2 for fast walking on a random trajectory.
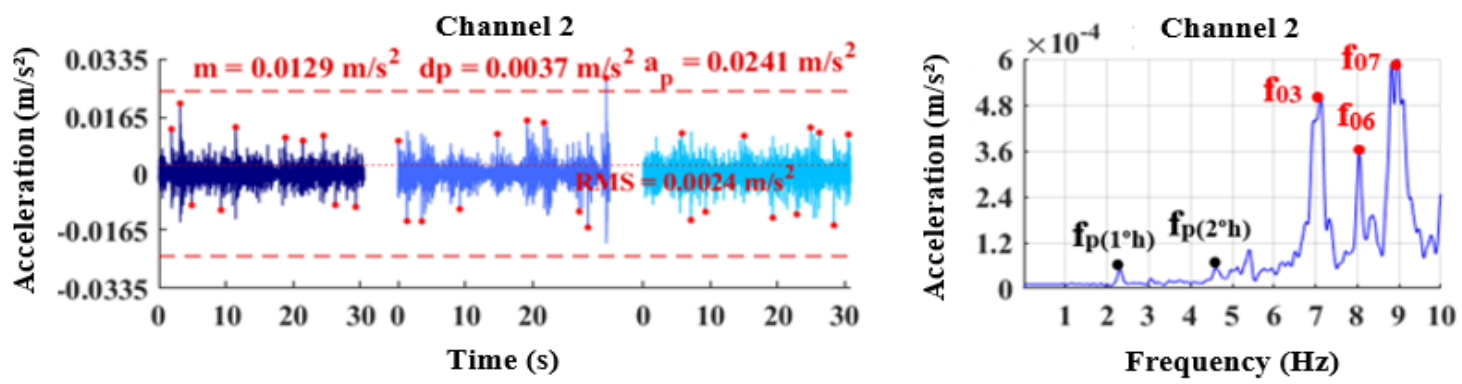

Figure 13. Dynamic response from floor 3 for fast walking on a random trajectory.
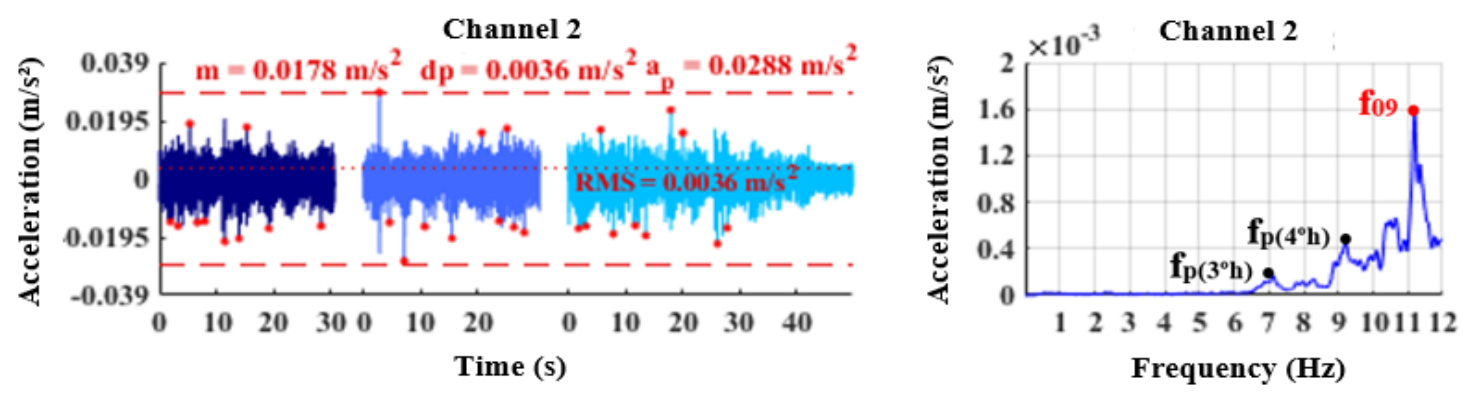

Figure 14. Dynamic response from floor 4 for fast walking on a random trajectory. 

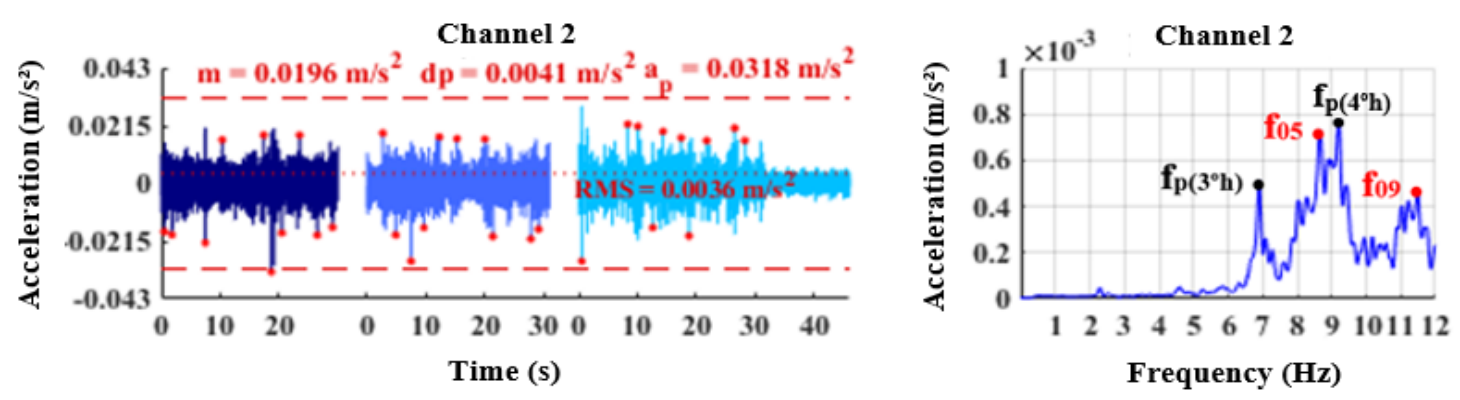

Figure 15. Dynamic response from floor 5 for fast walking on a random trajectory.

Three tests were performed for each direction and step frequency. The shades of blue shown in Figures 11 to 15 represent each of the three tests performed. The maximum peak acceleration that could occur on each floor, for each direction and step frequency, was determined from a probabilistic analysis, considering a confidence level equal to $99.7 \%(3 \sigma)$. To calculate mean peak acceleration, the ten highest values obtained in each test (in module) were used, totalling thirty values, identified in Figures 11 to 16 by the red dots, followed by the standard deviation calculation. The results found for mean $(m)$, standard deviation $\left(d_{p}\right)$ and peak acceleration $\left(a_{p}\right)$ are shown in the graphs above the red dashed line. The red dashed lines in Figures 11 to 16 indicate a confidence interval of $3 \sigma$, thus indicating that in $99.7 \%$ of cases maximum peak acceleration would occur within this range.

The maximum peak acceleration values and RMS found in this experimental investigation are summarized in Table 3. The results demonstrate that the maximum value of peak acceleration occurred when the user was walking fast ( $\mathrm{fp}=$ $2.3 \mathrm{~Hz}$ ). In tests performed on floor 1 considering the walking of four people, the greatest acceleration responses were also obtained for the fast-walking situation (see Figure 16).

Table 3. Comparison of the accelerations obtained on the five floors with normative limits.

\begin{tabular}{|c|c|c|c|c|c|}
\hline Floor & $\begin{array}{c}\text { People } \\
\text { quantity }\end{array}$ & Maximum Peak Acceleration $\left(\mathrm{m} / \mathrm{s}^{2}\right)$ & $\begin{array}{c}\text { Human Comfort } \\
\text { AISC }\end{array}$ & $\begin{array}{c}\text { Maximum RMS } \\
\text { Acceleration } \\
\left(\mathbf{m} / \mathbf{s}^{2}\right) \\
\end{array}$ & $\begin{array}{c}\text { Human } \\
\text { Comfort ISO } \\
2631-2 \\
\end{array}$ \\
\hline 1 & 1 & 0.028 & Acceptable & 0.0026 & Acceptable \\
\hline 2 & 1 & 0.031 & Acceptable & 0.0031 & Acceptable \\
\hline 3 & 1 & 0.024 & Acceptable & 0.0024 & Acceptable \\
\hline 4 & 1 & 0.029 & Acceptable & 0.0036 & Acceptable \\
\hline 5 & 1 & 0.032 & Acceptable & 0.0036 & Acceptable \\
\hline 1 & 4 & 0.061 & Unacceptable & 0.0045 & Acceptable \\
\hline
\end{tabular}
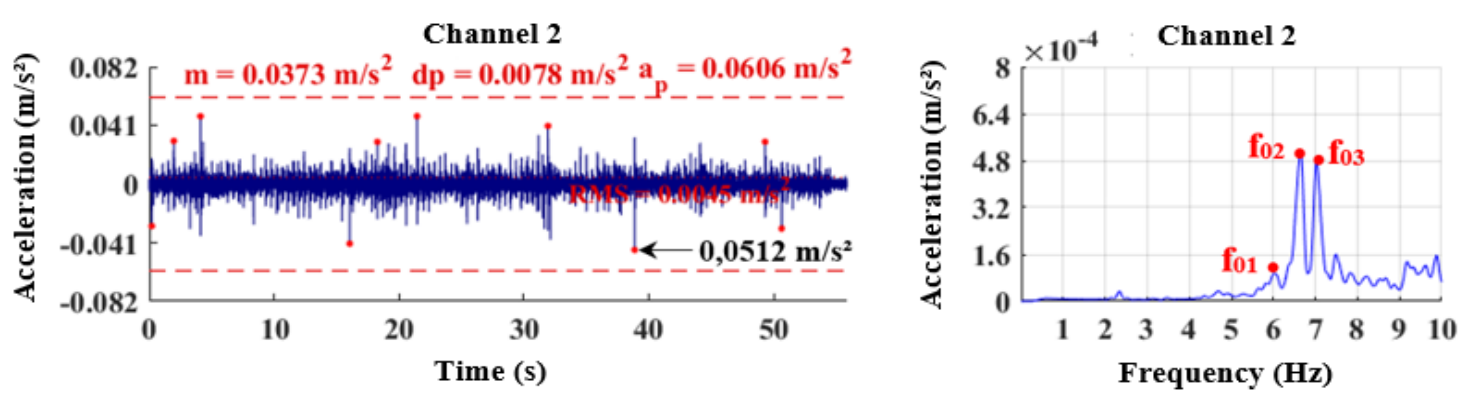

Figure 16. Dynamic response from floor 1 for four fast walking people on a random trajectory. 


\subsection{Human comfort}

The suitability of the floor under study was verified when subjected to human walking in terms of discomfort related to vibrations. In this way, the dynamic responses found in the experimental dynamic analysis for the five floors were compared with the limit values proposed by technical literature of AISC DG 11 [1], of ISO 2631-2 [28] and Brazilian standards ABNT NBR 8800:2008 [30] and ABNT NBR 6118:2014 [15].

It is worth mentioning that the structure, during monitoring, was not finalized, pending the finishes, internal partitions, external closings, installations, among others. The inclusion of these components increases the damping rates and attenuates the structure vibration levels, being therefore favourable to the comfort of users.

According to the recommendations of ABNT NBR 8800:2008 [30], in the case of structures subject to constant walking actions such as offices and similar structures, the value of $4 \mathrm{~Hz}$ is indicated as the lower limit for the floor fundamental frequency. Thus, as the first natural frequency of the system floor is $5.90 \mathrm{~Hz}$, it is concluded that this structure meets the criteria adopted by this standard. However, it is emphasized that, according to ABNT NBR 8800:2008 [30], these criteria start from the assumption of a simplified assessment of vibration generated by human activities and may not represent an ideal solution to the problem. Thus, it is recommended that structural designs assess the problems of floor vibrations through a dynamic analysis.

Floors comfort was also analysed according to the recommendations of NBR 6118:2014 [15]. For structures intended for office occupation, a most compatible case for the destination of the floors under study, this standard recommends that the structure fundamental frequency be $20 \%$ away from the critical frequency $(4 \mathrm{~Hz})$. Thus, as the floor's first natural frequency is $5.90 \mathrm{~Hz}$, it may be concluded that this structure meets the criteria recommended by this standard. The criteria recommended by ABNT NBR 6118:2014 [15] assume that removing the first natural frequency from the resonance structure with the first two harmonics of human walking is sufficient. However, cases of resonance even with the fourth harmonic of walking are observed, as concluded by other authors. Thus, the critical frequency for the office cases, for example, should be at least $8 \mathrm{~Hz}$. It is also noteworthy that a method of assessing excessive vibration based only on analysis of minimum frequencies is not advisable, as the structure can present uncomfortable vibrations to its users even if there is no resonance with the excitation source (Varela [12]). In this way, the structure under study was also evaluated according to international standards and design guides, based on acceleration limits.

The AISC DG 11 [1] recommends that peak accelerations on a floor be limited to $0.5 \% \mathrm{~g}\left(0.049 \mathrm{~m} / \mathrm{s}^{2}\right)$ and, ISO 2631-2 [28] suggests a limit for RMS acceleration equal to $0.02 \mathrm{~m} / \mathrm{s}^{2}$. In both codes, the limits related to office occupation were chosen, since this is the activity that most resembles future building destination. The results of peak acceleration and RMS found for the five floors are summarized in Table 3, where they are compared to the limits proposed by the cited codes. It can be noted that the proposed human comfort criteria AISC DG 11 [1] and ISO 26312 [28] were met in all walking situations considering a person action over the five studied floors. Thus, it can be inferred that the investigated structural system, due to a person's walk, will not present human comfort problems.

However, analysing only the results obtained for floor 1, it is observed that the walking of four people at a frequency of $2.3 \mathrm{~Hz}$ resulted in a peak acceleration of $0.061 \mathrm{~m} / \mathrm{s}^{2}$, above the limit recommended by AISC DG 11 [1], while in the test with a person walking on floor 1 , with the same step frequency and the same trajectory, the value found was 0.028 $\mathrm{m} / \mathrm{s}^{2}$. From this analysis it is concluded that the increase in the number of people walking causes the increase in peak acceleration amplitudes. The increase, for floor 1, exceeded the limit established by AISC DG 11 [1] for human comfort.

It is evident that the number of users that make up the loading significantly affects the composite floor dynamic response investigated in this work. In this way, the relevance of carrying out tests is clear considering the variation in the number of people on the floor so that this activity is as close as possible to the real structure use situation. This fact must also be considered when designing such structures.

All the results obtained through the analyses refer to the structure's behaviour during its construction phase. Thus, the damping ratio found is not the final and it will undergo changes after the introduction of non-structural elements, such as ceilings and internal partitions. Another important point to note in the finished structure is the architecture layout, which will pre-determine the path users will take on the floor, which is an important factor for the development and analysis of the excitation.

\section{CONCLUSIONS}

The present work aimed to evaluate the experimental dynamic response of a real composite floor system under construction, located in Belo Horizonte/MG city, when subjected to dynamic excitations arising from human activities. 
Five typical floor panels of a building with a total area of $1300 \mathrm{~m}^{2}$ were instrumented, which, after completion, will be used as a teaching hospital of a medical school.

The investigated structure modal analysis was performed experimentally and numerically. The modal testing of the floors was carried out by dynamic monitoring using five seismic accelerometers installed on the slabs. Then, these results were calibrated with a finite element model developed in the ANSYS program. A good agreement was obtained between the experimental and numerical results, with differences between $0.2 \%$ and $5.2 \%$. Having in mind structural systems of multiple floors (several slab panels) with a relatively uniform stiffness distribution, as in this case, it was noted that the first natural frequencies are very close, showing the phenomenon of mode concentration, easily excited under human walking.

Forced vibration tests were carried out on the structure and each of the five floor panels were excited by human walking, considering three different step frequencies $(1.7 \mathrm{~Hz}, 2.0 \mathrm{~Hz}$ and $2.3 \mathrm{~Hz})$, and in different directions, aiming to guarantee the possible trajectory variability of future use of the floor by the occupants. The investigated five floor panels were evaluated according to the ABNT NBR 8800:2008 [30] and ABNT 6118:2014 [15] recommendations, and the results, based on the peak accelerations values, have indicated that the recommended limits were not violated. However, these criteria are overly simplistic and, in this research work it is suggested that these results can be used only for initial assessments and conceptual project of the floor, when subjected to human activity. It is recommended that slabs subjected to people activity can be evaluated by means of dynamic analysis considering the characteristics and nature of excitations, limits for human comfort depending on the use and occupation, structure natural frequencies, modal damping ratios and the effective mass.

Considering the vibration caused by walking, none of the slabs of the investigated steel-concrete composite floor violated the human comfort criteria proposed by AISC DG 11 [1] and ISO 2631-2 [28]. However, it must be emphasized that there are studies in the technical literature that aim to represent the influence of simultaneous multi-person walking scenarios on the dynamic behaviour of floors. Živanović et al. [31] and Chen et al. [32] have developed a research work comparing the vibration responses measured on an office floor, due to the single person walking and the simultaneous multi-person walking scenario on the same floor. The results found by Živanović et al. [31] have shown that occupants were exposed to lower vibrations during simultaneous multi-person walking when compared to those obtained when a single person was considered to all walking paths. On the other hand, the response obtained by Chen et al. [32] has shown that simultaneous walking scenarios considering two people resulted in higher peak acceleration values than those obtained in single person walking scenarios. It is crystal clear that the obtained results in different research works are conflicting and in the authors' point of view this is an indicative that the research associated to the dynamic structural behaviour and human comfort assessment of floors requires more investigation.

In this research work, the situation associated with multiple individuals walking on the structure was also investigated. This way, Floor 1 was subjected to the dynamic actions of four people walking freely, with different step velocities, which resulted in a significant increase in the peak acceleration and RMS values. This fact has indicated that the walking induced by a group of people can produce excessive vibrations on the floor. In this situation, the human comfort limits of AISC DG 11 [1] were surpassed. Thus, it must be emphasized that the dynamic structural behaviour of the studied steel-concrete composite floor presents strong relation with the number of people walking on the structure, and the relevance of carrying out more studies about this effect is evident. On the other hand, it is worth to mention that the structural system is in the final construction phase and certainly the damping ratio associated to the non-structural elements, for example, can improve the floor's dynamic performance.

In general, the human comfort analysis in terms of peak accelerations can lead to conservative values, since an isolated acceleration peak can compromise a floor that, in fact, during all the excitation, is hardly subject to this peak of vibration. However, considering the future use of the investigated building, as a teaching hospital, it is important to highlight that considering the floors where a high degree of comfort is required, such as operating rooms and precision instrument rooms, peak acceleration would have an adverse and considerable effect. The main criticism regarding the use of the RMS value is because this value presents little sensitivity to eventual shocks that occurred during the measurement time, since the sparse peaks have little influence on the final RMS values. Thus, the importance of analysing the structure according to the different criteria, having in mind the maximum acceleration values which occurred during experimental tests with their corresponding frequencies and RMS values is highly evident.

It should be noted that the study is instructive and does not aim to affirm that a design guide is more accurate than other. This way, a contribution is presented based on the assess the steel-concrete composite floors structural behaviour when subjected to dynamic excitations associated with people's walking. Finally, this investigation emphasizes the importance of the structural engineers to be knowledgeable about the activities performed on the structural system, 
aiming the development of a rational and optimized project, according to current procedures foreseen in the standards and design recommendations based on human comfort criteria.

\section{ACKNOWLEDGEMENTS}

The authors gratefully acknowledge the support and information provided by the company CODEME S.A. and the financial support for this research work provided by the Brazilian Science Foundation's CNPq, CAPES and FAPERJ.

\section{REFERENCES}

[1] T. M. Murray, D. E. Allen, E. E. Ungar, and D. B. Davis, Vibrations of Steel-Framed Structural Systems Due to Human Activity, 2nd ed. USA: AISC, 2016.

[2] M. Willford and P. A. Young, Design Guide for Footfall Induced Vibration of Structures (Steel Design Guide Series). Trowbridge, UK: The Concrete Society Publication, 2006.

[3] M. Feldmann, C. Heinemeyer, and C. Butz, Design of Floor Structures for Human Induced Vibrations (JRC Scientific and Technical Reports). Brussels: European Comission, 2009.

[4] A. Smith, S. Hick, and P. Devine, Design of Floors for Vibration: A New Approach (SCI Publication). Ascot, UK: The Steel Construction Institute, 2009. https://doi.org/10.13140/RG.2.2.29342.95048.

[5] S. J. Hicks and A. L. Smith, "Design of floor structures against human induced vibrations," Steel Constr., vol. 4, no. 2, pp. 114-120, 2011. http://dx.doi.org/10.2788/4640.

[6] W. D. Varela and R. C. Battista, "Control of vibrations induced by people walking on large span composite floor decks," Eng. Struct., vol. 33, pp. 2485-2494, 2011. http://dx.doi.org/10.1016/j.engstruct.2011.04.021.

[7] H. A. T. Nguyen, "Walking induced floor vibration design and control," Ph.D. thesis, Fac. Eng. Ind. Scienc. Swinburne Univ. Tec., Melbourne, Australia, 2013.

[8] A. Pavic and P. Reynolds, "Experimental assessment of vibration serviceability of existing office floors under human-induced excitation," Exp. Tech., vol. 23, pp. 41-45, 1999. http://dx.doi.org/10.1111/j.1747-1567.1999.tb01305.x.

[9] S. M. Homem, Control of Human Induced Floor Vibrations. Cambridge: Massachusetts Institute of Technology, 2014.

[10] S. Berczynsky and T. Wroblewski, "Experimental verification of natural vibration models of steel-concrete composite beams," J. Vib. Control, vol. 16, pp. 2057-2081, 2010. http://dx.doi.org/10.1177/1077546309350552.

[11] P. Dallard et al., "The London Millennium Footbridge,”" Struct. Eng., vol. 79, pp. 17-33, 2001.

[12] W. D. Varela, "Modelo teórico-experimental para análise de vibrações induzidas por pessoas caminhando sobre lajes de edifícios," Ph.D. thesis, Univ. Estad. Rio Jan., Rio de Janeiro, Brasil, 2004.

[13] J. M. W. Brownjohn and C. Middleton, “Efficient dynamic performance assessment of a footbridge,” J. Bridge Eng., vol. 158, no. 4, pp. 185-192, 2005.

[14] T. D. Araújo, and Y. C. V. Costa, "Evaluation of dynamic behaviour of waffle slab to gym center," Lat. Am. J. Solids Struct., vol. 11, pp. 1114-1131, 2014. http://dx.doi.org/10.1590/S1679-78252014000700004.

[15] Associação Brasileira de Normas Técnicas. Projeto de Estruturas de Concreto, NBR 6118, 2014.

[16] C. M. R. Gaspar "Avaliação do efeito da interação humana sobre pisos de edificações submetidos a atividades humanas rítmicas," Ph.D. thesis, Univ. Estad. Rio Jan., Rio de Janeiro, Brasil, 2018.

[17] S. Nakamura, T. Kawasaki, H. Katsuura, and K. Yokoyama, "Experimental studies on lateral forces induced by pedestrians," $J$ Constr Steel Res., vol. 64, no. 2, pp. 247-252, 2008.

[18] Y. Matsumoto and M. J. Griffin, "Comparison of biodynamic responses in standing and seated human bodies," J. Sound Vibrat., vol. 238, pp. 691-704, 2000. http://dx.doi.org/10.1006/jsvi.2000.3133.

[19] E. Shahabpoor, A. Pavic, and V. Racic, "Interaction between walking humans and structures in vertical direction: a literature review," Shock Vib., vol. 2016, pp. 1-22, 2016. http://dx.doi.org/10.1155/2016/3430285.

[21] F. Venuti, V. Racic, and A. Corbetta, "Pedestrian-structure interaction in the vertical direction: coupled oscillator-force model for vibration serviceability assessment", in Proc. 9th Internat. Conf. Struct. Dynam, EURODYN 2014, Porto, Portugal, 2014, pp. 915920.

[22] S. Zhang and L. Xu, "Human-induced vibration of cold-formed steel floor systems: Parametric studies," Adv. Struct. Eng., vol. 23, no. 10, pp. 2030-2043, 2020. http://dx.doi.org/10.1177/1369433220904013.

[23] B. E. Ferreira, "Análise numérico-experimental de vibrações induzidas pelo caminhar humano sobre pisos mistos (aço-concreto)," M.S. thesis, Univ. Fed. Minas Ger., Belo Horizonte, Brasil, 2020.

[24] Associação Brasileira de Normas Técnicas. Alvenaria Estrutural-Blocos Cerâmicos. Parte 1: Projetos, ABNT NBR 15812-1, 2010.

[25] ANSYS Swanson Analysis Systems Inc. “Theory reference (version 12.1)”, USA: ANSYS, Inc., 2009. 
[26] A. Brandt, Noise and Vibration Analysis. Signal Analysis and Experimental Procedures, Hoboken: John Wiley \& Sons, Inc., 2011.

[27] A. Cunha and E. Caetano, "Experimental modal analysis of civil engineering structures," J. Sound Vibrat., vol. 40, pp. 12-20, 2006.

[28] International Standard Organization. Mechanical Vibration and Shock - Evaluation of Human Exposure to Whole-body VibrationPart 2: Vibration in Buildings (1 Hz to $80 \mathrm{~Hz}$ ), ISO 2631-2, 2003.

[29] International Standard Organization. Evaluation of Human Exposure to Whole-body Vibration: General Requirements, ISO 2631-1, 1997.

[30] Associação Brasileira de Normas Técnicas. Projeto de Estruturas de Aço e de Estruturas Mistas de Aço e Concreto de Edificios, NBR 8800, 2008.

[31] S. Živanović, A. Pavic, and V. Racic "Towards modelling in-service pedestrian loading of floor structures," in Proc. 30th IMAC, A Conf on Struct. Dynam.: Top. Dynam. Civ. Struct., New York, pp. 85-94, 2012. https://doi.org/10.1007/978-1-4614-2413-0

[32] S. Chen, J. Zhang, and R. Zhang "Human-induced vibration of steel-concrete composite floors," in Proc. Inst. Civ. Eng: Struct. Build., pp. 50-63, 2018. https://doi.org/10.1680/jstbu.16.00179.

Author contributions: BEF: conceptualization, writing, data acquisition, formal analysis, methodology; HC and JGSS: supervision, formal analysis; RBC: supervision; JVA: data acquisition.

Editor: Ricardo Carrazedo, Guilherme Aris Parsekian. 